\title{
Examining the fixation kinetics of chelated and non-chelated copper and the applications to micronutrient management in semiarid alkaline soils
}

\author{
T. K. Udeigwe ${ }^{1}$, M. B. Eichmann ${ }^{1,2}$, M. C. Menkiti ${ }^{3}$, and N. Y. O. Kusi ${ }^{1}$ \\ ${ }^{1}$ Department of Plant and Soil Science, Texas Tech University, Lubbock, Texas 79409, USA \\ ${ }^{2}$ Albrecht Daniel Thaer-Institut für Agrar- und Gartenbauwissenschaften, Humboldt University Berlin, \\ Unter den Linden 6, 10099 Berlin, Germany \\ ${ }^{3}$ Department of Chemical Engineering, Nnamdi Azikiwe University, Awka, Nigeria
}

Correspondence to: T. K. Udeigwe (theo.udeigwe@ttu.edu)

Received: 11 September 2015 - Published in Solid Earth Discuss.: 15 October 2015

Revised: 30 December 2015 - Accepted: 12 January 2016 - Published: 24 February 2016

\begin{abstract}
This study examined and compared the fixation and fixation kinetics of copper $(\mathrm{Cu})$ in chelated (ethylene diamine tetraacetic acid, EDTA) and non-chelated mixed systems of micronutrients in the semiarid soils of the Southern High Plains, USA, using findings from $\mathrm{Cu}$ extraction studies and kinetic models. Approximately, $22 \%$ more $\mathrm{Cu}$ was fixed in the non-chelated system compared to the chelated within the first 14 days with only $7 \%$ difference between the two systems by day 90 . Findings suggest a decrease in the effectiveness of chelated micronutrients over time, highlighting the significance of timing even when chelated micronutrients are used. The strengths of the relationship of change in available $\mathrm{Cu}$ with respect to other micronutrients (iron $(\mathrm{Fe})$, manganese $(\mathrm{Mn})$, and zinc $(\mathrm{Zn})$ ) were higher in the nonchelated system $\left(R^{2}: 0.68-0.94\right)$, compared to the chelated $\left(R^{2}: 0.42-0.81\right)$, with slopes of $0.40(\mathrm{Cu}-\mathrm{Fe}), 0.31(\mathrm{Cu}-\mathrm{Mn})$, and $1.04(\mathrm{Cu}-\mathrm{Zn})$ in the non-chelated system and $0.26(\mathrm{Cu}-$ $\mathrm{Fe}), 0.22(\mathrm{Cu}-\mathrm{Mn})$, and $0.90(\mathrm{Cu}-\mathrm{Zn})$ in the chelated system. Reduction in the amount of available $\mathrm{Cu}$ was best described by the power function model $\left(R^{2}=0.91, \mathrm{SE}=0.081\right)$ in the non-chelated system and second-order model $\left(R^{2}=0.95\right.$, $\mathrm{SE}=0.010)$ in the chelated system. The applications generated from this study could be used as tools for improved micronutrient management and also provide baseline data for future work in other semiarid/arid alkaline soils of the world. Findings are also more applicable to field settings, an improvement over related previous studies.
\end{abstract}

\section{Introduction}

Malnutrition resulting from lack of adequate micronutrients in foods, a situation that could be partly attributed to the ease of micronutrient fixation in soil systems, contributes significantly to the global burden of disease (WHO, 2000). The fate of the plant-available portion of micronutrients is controlled by a number of soil factors including soil $\mathrm{pH}$, organic matter (OM), texture, aeration status, calcium carbonate $\left(\mathrm{CaCO}_{3}\right)$, iron $(\mathrm{Fe})$ oxides, and interaction with other micronutrients, etc. (Havlin et al., 2013; Fernández-Calviño et al., 2013). Plant availability of micronutrients could be a bigger challenge in calcareous or alkaline soils due to their high pH (Rashid and Ryan, 2004; Alloway, 2008). High soil pH leads to decreased solubility and increased fixation of most micronutrients such as copper $(\mathrm{Cu})$, zinc $(\mathrm{Zn}), \mathrm{Fe}$, and manganese $(\mathrm{Mn})$ in such soils, leading to reduction in the plantavailable portion (Sparks, 2003; Havlin et al., 2013). For Cu, apart from $\mathrm{pH}$, reduction in availability resulting from its interaction with OM functional groups, particularly in soils treated with organic amendments such as animal manure and biosolids, has also been well documented (De Schamphelaere et al., 2004; Pinto et al., 2004). Its availability has also been reported to increase with soil OM (under moderate OM level) and clay content, and to decrease with an increase in $\mathrm{pH}$ and $\mathrm{CaCO}_{3}$ (Alloway, 2008). Interactions among nutrients resulting in antagonism are also common (Dimkpa et al., 2013; Havlin et al., 2013; Bindraban et al., 2015), for instance, plant uptake of $\mathrm{Cu}$ is shown to be reduced by ele- 
vated soil concentrations of other micronutrients such as $\mathrm{Zn}$ and $\mathrm{Fe}$, as well as the macronutrient phosphorus (P) (Havlin et al., 2013).

Given the aforementioned challenges, to increase the availability of micronutrients such as $\mathrm{Cu}$ to plants, they are preferably applied in the form of synthetic and organic chelates. The advantages of the chelated forms have also been documented under certain soil types and conditions by a number of researchers (Kayser et al., 2000; Sekhon, 2003; Luo et al., 2005; Chiu et al., 2005). However, the heterogeneous nature of soil limits the extension of findings from one soil type to another among regions, thus, often necessitating site-specific studies.

The soils of the Southern High Plains (SHP) of the USA are of the semiarid climate and are characteristically alkaline in nature. As can be likened to other arid to semiarid regions of the world (Amuti et al., 2014; Sarah and Zonana, 2015; Torres et al., 2015; Barbero-Sierra et al., 2015; Mureithi et al., 2015), this region (the SHP) is currently facing complex environmental challenges such as drought, declining groundwater quality, wind erosion, and soil salinization that limit agricultural productivity (Mehta et al., 2000; Stout, 2001; Allen et al., 2005; Young et al., 2015). Recent observations have also revealed an increasing number of cases of micronutrient deficiency, which could be attributed to the characteristically high $\mathrm{pH}$ soils prevalent in this region and intensive crop production activities. Unfortunately, little to no information is available on the chemistry of micronutrients in the semiarid alkaline soils of this region, despite the agronomic significance of these soils. Understanding the kinetics of plant-available micronutrient fixation in these soils is vital for developing improved nutrient management plans for agricultural and environmental sustainability. Kinetic parameters obtained can be used for comparisons among micronutrients and among soils. A systematic approach to examining the chemistry of micronutrients in soil systems will encompass the examination of the chemistry of these micronutrients in a mixed system (of a number of other micronutrients).

Although a number of studies have examined the kinetics of micronutrient fixation in soils (Manouchehri et al., 2006; Reyhanitabar and Gilkes, 2010; Abbas and Salem, 2011), the experimental conditions (e.g., sample size, reaction times) of these studies often limit the transferability of findings to field settings. This study was prompted by the limitations identified in the previous studies and the generally limited information on this subject area. A literature search indicates that the following questions are still largely unanswered: (i) How much of applied plant-available $\mathrm{Cu}$ will be present at a specific time? (ii) What are the reaction rates and mechanism of $\mathrm{Cu}$ fixation in these soils? (iii) How do the findings from i and ii compare to those of other micronutrients? (iv) How would the findings from i, ii, and iii vary among chelated and non-chelated micronutrient compounds in these semiarid soils? Thus, the objectives of this study were to examine and compare the fixation and fixation kinetics of $\mathrm{Cu}$ in chelated (ethylene diamine tetraacetic acid, EDTA) and non-chelated mixed systems in the semiarid soils of the SHP, US. Findings from this study could be extended to other semiarid to arid regions of the world facing similar environmental challenges.

\section{Materials and methods}

\subsection{Soil description and sampling}

Soil samples were collected from three different crop production sites in west Texas. Sampling was restricted to the depths of $0-15 \mathrm{~cm}$ (surface) and $15-30 \mathrm{~cm}$ (subsurface) on representative soils from three important agricultural soil series in the SHP, namely the Amarillo (A), Pullman (P), and Mansker (M), for a total of six composite soil samples (Table 1). Soils and sites of interest were identified using the Web Soil Survey (WSS) of the Natural Resources Conservation Service (NRCS). Soil samples were collected using a digging spade marked at $0-15$ and $15-30 \mathrm{~cm}$ depths. At each field, representative soil samples were collected from approximately $12-15$ spots within the field and combined to get a composite sample of about $10 \mathrm{~kg}$ of each soil depth. The selected depths are the typical ones commonly examined in most soil fertility and nutrient management studies (Havlin et al., 2013).

\subsection{Soil characterization}

A subsample of each original (untreated) soil was ground, passed through a $2 \mathrm{~mm}$ sieve, and stored in plastic bags at a room temperature of approximately $23^{\circ} \mathrm{C}$. Soil samples were analyzed for a suite of chemical and physical properties. Soil $\mathrm{pH}_{1: 2}$ and $\mathrm{EC}_{1: 2}$ were determined on a $1: 2$ soil / water ratio using the applicable methods described by Sparks et al. (1996). Soil OM was estimated using the loss on ignition method (at $400{ }^{\circ} \mathrm{C}$ and $8 \mathrm{~h}$ ) following the procedure by Nelson and Sommers (1982). Percentages of $\mathrm{CaCO}_{3}$ were determined using the tensimeter method 4E and 4E1 of the United States Department of Agriculture NRCS-Soil Survey Investigation Report (Soil Survey Staff, 2014). Soil particle size was determined using the modified hydrometer method as described by Gee and Bauder (1986). Plant-available micronutrients $(\mathrm{Cu}, \mathrm{Fe}, \mathrm{Mn}$, and $\mathrm{Zn})$ were determined using diethylene triamine pentaacetic acid (DTPA) extraction following the procedure by Lindsay and Norvell (1978). Soil test P was determined using the Mehlich 3 procedure (Mehlich, 1984). Total elemental analysis was conducted with the DigiPREP digestion system using USEPA Method 3050B. Concentrations of elements in all extracts were measured using inductively coupled plasma optical emission spectroscopy (ICPOES; iCAP 7400, Thermo Scientific, Waltham, MA). 
Table 1. Soil classification and identification of selected semiarid alkaline soils of the Southern High Plains, USA.

\begin{tabular}{|c|c|c|c|c|c|c|c|c|c|c|c|}
\hline \multirow{2}{*}{$\begin{array}{l}\text { Soil series } \\
\text { (classification) }\end{array}$} & \multirow{2}{*}{$\begin{array}{l}\text { Sample } \\
\text { ID }\end{array}$} & \multirow{2}{*}{$\begin{array}{l}\text { Depth } \\
(\mathrm{cm})\end{array}$} & \multirow{2}{*}{$\begin{array}{r}\text { Sampling } \\
\text { location }\end{array}$} & \multirow[t]{2}{*}{$\mathrm{pH}$} & \multirow{2}{*}{$\begin{array}{c}\mathrm{EC} \\
\left(\mathrm{dS} \mathrm{m^{-1 }}\right)\end{array}$} & $\mathrm{OM}$ & $\mathrm{CaCO}_{3}$ & Clay & Sand & Silt & \multirow{2}{*}{$\begin{array}{l}\text { Textural } \\
\text { class }\end{array}$} \\
\hline & & & & & & & & $(\%)$ & & & \\
\hline $\begin{array}{l}\text { Amarillo } \\
\text { (fine-loamy, mixed, } \\
\text { superactive, thermic } \\
\text { Aridic Paleustalfs) }\end{array}$ & $\begin{array}{l}\mathrm{A}_{\mathrm{a}} \\
\mathrm{A}_{\mathrm{b}}\end{array}$ & $\begin{array}{l}0-15 \\
15-30\end{array}$ & $\begin{array}{r}33.6058^{\circ} \mathrm{N} ; \\
101.9073^{\circ} \mathrm{W}\end{array}$ & $\begin{array}{l}8.07 \\
8.35\end{array}$ & $\begin{array}{l}0.24 \\
0.22\end{array}$ & $\begin{array}{l}1.05 \\
0.93\end{array}$ & $\begin{array}{l}2.41 \\
5.59\end{array}$ & $\begin{array}{l}17.8 \\
24.0\end{array}$ & $\begin{array}{l}74.9 \\
64.2\end{array}$ & $\begin{array}{l}7.40 \\
11.8\end{array}$ & $\begin{array}{l}\text { SL } \\
\text { SCL }\end{array}$ \\
\hline $\begin{array}{l}\text { Mansker } \\
\text { (coarse-loamy, } \\
\text { carbonatic, thermic } \\
\text { Calcidic Paleustolls) }\end{array}$ & $\begin{array}{l}\mathrm{M}_{\mathrm{a}} \\
\mathrm{M}_{\mathrm{b}}\end{array}$ & $\begin{array}{l}0-15 \\
15-30\end{array}$ & $\begin{array}{r}34.1261^{\circ} \mathrm{N} ; \\
101.5899^{\circ} \mathrm{W}\end{array}$ & $\begin{array}{l}8.12 \\
8.20\end{array}$ & $\begin{array}{l}0.27 \\
0.25\end{array}$ & $\begin{array}{l}1.63 \\
1.24\end{array}$ & $\begin{array}{l}0.98 \\
0.13\end{array}$ & $\begin{array}{l}27.9 \\
41.9\end{array}$ & $\begin{array}{l}56.5 \\
40.9\end{array}$ & $\begin{array}{l}15.6 \\
17.2\end{array}$ & $\begin{array}{c}\text { SCL } \\
\mathrm{C}\end{array}$ \\
\hline $\begin{array}{l}\text { Pullman (fine, mixed, } \\
\text { superactive, thermic } \\
\text { Torrertic Paleustolls) }\end{array}$ & $\begin{array}{l}\mathrm{P}_{\mathrm{a}} \\
\mathrm{P}_{\mathrm{b}}\end{array}$ & $\begin{array}{l}0-15 \\
15-30\end{array}$ & $\begin{array}{l}34.05901^{\circ} \mathrm{N} ; \\
101.4773^{\circ} \mathrm{W}\end{array}$ & $\begin{array}{l}7.52 \\
8.02\end{array}$ & $\begin{array}{l}0.22 \\
0.24\end{array}$ & $\begin{array}{l}1.56 \\
1.57\end{array}$ & $\begin{array}{l}2.34 \\
4.16\end{array}$ & $\begin{array}{l}32.8 \\
33.0\end{array}$ & $\begin{array}{l}39.9 \\
38.7\end{array}$ & $\begin{array}{l}27.3 \\
28.3\end{array}$ & $\begin{array}{l}\mathrm{CL} \\
\mathrm{CL}\end{array}$ \\
\hline
\end{tabular}

SCL: sandy clay loam; SL: sandy loam; CL: clay loam; C: clay; EC: electrical conductivity; OM: organic matter.

\subsection{Sample preparation and treatment application}

Each composite soil sample was thoroughly mixed and a representative portion taken to fill a $4 \mathrm{~L}$ plastic pot. Sorghum (Sorghum bicolor) was then planted and grown over a period of 35 days in the greenhouse with no nutrients added. This practice was optional and primarily aimed at depleting the original micronutrient level of the soils prior to treatment application. Following this practice, samples were crushed, air dried, thoroughly mixed, ground, and passed through a $2 \mathrm{~mm}$ sieve. Two sets of $250 \mathrm{~g}$ samples were weighed from each soil. One set was treated with a mixture of chelated (EDTA) micronutrients and the other with a mixture of non-chelated micronutrients, using $80 \mathrm{~mL}$ solution of each fertilizer compound's mixture, prepared in order to add $5 \mathrm{mg}$ of each micronutrient $(\mathrm{Cu}, \mathrm{Mn}, \mathrm{Zn}$, and $\mathrm{Fe})$ to $1 \mathrm{~kg}$ of soil. The non-chelated micronutrient compounds used were $\mathrm{CuSO}_{4} \cdot 5 \mathrm{H}_{2} \mathrm{O}, \mathrm{MnSO}_{4} \cdot \mathrm{H}_{2} \mathrm{O}, \mathrm{ZnSO}_{4} \cdot \mathrm{H}_{2} \mathrm{O}$, and $\mathrm{FeSO}_{4} \cdot 7 \mathrm{H}_{2} \mathrm{O}$, and the chelated compounds were $\mathrm{Cu}$ EDTA, Mn-EDTA, Zn-EDTA, and Fe-EDTA. There were a total of six soil samples and two sets of micronutrient amendments for a total of 12 soil-fertilizer treatments, each replicated twice. Subsamples were taken from each treated sample at $2,5,7,14,21,28,35,49,63,77$, and 90 days after treatment and analyzed for plant-available micronutrients using a DTPA extraction technique (Lindsay and Norvell, 1978). After each subsampling event, the remaining soil samples were wetted with water to approximately field capacity. Within the first 7 days, the soils were wetted after each subsampling; however, after the first 7 days, sampling was conducted at 7-14 days intervals, so the soil samples were watered every 7 days. The periodic wetting of the soil was to simulate the wetting and drying cycle obtainable under field conditions and also provide a medium to facilitate chemical reactions in the soil.

\subsection{Extraction procedure}

The preparation of DTPA extractant and the extraction procedure followed the method described by Lindsay and Norvell (1978), the most commonly used technique for extracting available micronutrient cations such as $\mathrm{Fe}, \mathrm{Mn}, \mathrm{Cu}$, and Zn (Liang and Karamanos, 1993). Briefly, $10 \mathrm{~g}$ of airdried soil were placed in a $50 \mathrm{~mL}$ plastic tube and $20 \mathrm{~mL}$ of DTPA extracting solution was added. The tubes were placed on a reciprocal shaker for $2 \mathrm{~h}$ at approximately $25^{\circ} \mathrm{C}$ and 180 oscillations per minute. After shaking, samples were centrifuged for $10 \mathrm{~min}$ at $4000 \mathrm{rpm}$, and the resulting solutions were filtered into $16 \mathrm{~mm}$ borosilicate glass tubes using Whatman ${ }^{\circledR} 2$ filter paper. Soil extraction was conducted in duplicate. All filtrates were analyzed for $\mathrm{Fe}, \mathrm{Cu}, \mathrm{Zn}$, and Mn using ICP-OES (iCAP 7400, Thermo Scientific, Waltham, MA) following USEPA Method 200.7 (USEPAICP Users Group, 1982). Instrument calibration was performed using standard reference materials and checked using second source standards from a different vendor. Check samples were inserted after every 20-25 samples. The relative percentage difference between duplicates was also examined and $10 \%$ was set as the acceptance standard.

\subsection{Statistical analyses}

Statistical analyses were performed using statistical analysis software (SAS 9.4; SAS Institute, Cary, NC, USA). Where applicable, differences among means were examined using PROC GLM, and a mean comparison was conducted using Fisher's Least Significance Difference test at $\alpha$ level of 0.05 . The data obtained from the kinetic studies were fitted to selected kinetic models (Table 6) to derive the needed parameters using the PROC NLIN procedure. Single linear regression analyses used in examining changes in available $\mathrm{Cu}$ 
Table 2. Soil total element analysis of the studied semiarid alkaline soils (in $\mathrm{mg} \mathrm{kg}^{-1}$ ) of the Southern High Plains, USA.

\begin{tabular}{|c|c|c|c|c|c|c|c|c|c|c|c|c|c|}
\hline Series & Soil ID & $\mathrm{Al}$ & B & $\mathrm{Ca}$ & $\mathrm{Cu}$ & $\mathrm{Fe}$ & K & $\mathrm{Mg}$ & $\mathrm{Mn}$ & Mo & $\mathrm{P}$ & $\mathrm{Pb}$ & $\mathrm{Zn}$ \\
\hline \multirow[t]{2}{*}{ Amarillo } & $\mathrm{A}_{\mathrm{a}}$ & 17187 & 30.9 & 1823 & 5.50 & 11946 & 2848 & 2537 & 170 & 1.00 & 375 & 41.1 & 44.5 \\
\hline & $A_{b}$ & 13823 & 31.7 & 4307 & 5.60 & 9623 & 2791 & 2205 & 144 & 0.90 & 197 & 34.8 & 41.6 \\
\hline \multirow[t]{2}{*}{ Mansker } & $\mathrm{M}_{\mathrm{a}}$ & 13808 & 35.1 & 21008 & 6.10 & 9552 & 3004 & 2341 & 135 & 6.80 & 186 & 33.7 & 51.5 \\
\hline & $\mathrm{M}_{\mathrm{b}}$ & 16840 & 35.1 & 11584 & 7.10 & 11856 & 3554 & 3103 & 202 & 7.00 & 158 & 41.5 & 59.1 \\
\hline \multirow[t]{2}{*}{ Pullman } & $\mathrm{P}_{\mathrm{a}}$ & 11571 & 33.8 & 7252 & 6.10 & 8191 & 2926 & 2015 & 128 & 0.70 & 196 & 32.1 & 42.8 \\
\hline & $\mathrm{P}_{\mathrm{b}}$ & 12943 & 33.7 & 14433 & 6.00 & 8964 & 3029 & 2199 & 130 & 0.70 & 215 & 33.4 & 41.6 \\
\hline Mean & & 14362 & 33.4 & 10068 & 6.07 & 10022 & 3025 & 2400 & 152 & 2.85 & 221 & 36.1 & 46.9 \\
\hline Standard deviation & & 2215 & 1.74 & 7073 & 0.57 & 1544 & 274 & 386 & 29.1 & 3.14 & 77.6 & 4.12 & 7.05 \\
\hline
\end{tabular}

with respect to other micronutrients were conducted using the PROC REG procedure.

\section{Results and discussions}

\subsection{Soil characteristics}

Selected chemical and physical properties of the studied soils are summarized in Table 1. Average soil $\mathrm{pH}$ was 8.05. Soil $\mathrm{pH}$ was generally higher in the $15-30 \mathrm{~cm}$ depth by $0.08,0.28$, and $0.50 \mathrm{pH}$ units for the Mansker, Amarillo, and Pullman soil series, respectively. The average soil OM content was $1.33 \%$, falling within a range of 0.93 to $1.57 \%$ among soil depths. These values are typical of the semiarid alkaline soils of the SHP. Average soil EC value was $0.24 \mathrm{dS} \mathrm{m}^{-1}$, falling within a narrow range of $0.22-0.27 \mathrm{dS} \mathrm{m}^{-1}$. The observed soil EC values indicate that these agricultural soils are not salt impacted. Calcium carbonate content varied from 0.13 to $5.59 \%$ among depths and were almost twofold higher in the $15-30 \mathrm{~cm}$ depth in the Amarillo and Pullman soils. Average clay contents within the $0-15$ and $15-30 \mathrm{~cm}$ depths were 26.2 and $32.9 \%$, respectively, with a difference of 0.24 , 6.2, and $14.1 \%$ for Pullman, Amarillo, and Mansker, respectively. Accordingly, the textural classes vary from sandy loam (Amarillo) to clay (Mansker) as presented in Table 1. The soil properties discussed here are typical of those of soils of the semiarid climates (Chesworth, 2008).

The results of the total elemental analysis are presented in Table 2. The concentrations of elements such as $\mathrm{Ca}, \mathrm{Mg}$, $\mathrm{Na}, \mathrm{K}$, and $\mathrm{P}$ in these semiarid soils are typical of those of most agricultural soils (Adriano, 2001; Udeigwe et al., 2009), particularly those not receiving any form of organic amendments. Likewise, the concentrations of heavy metals such as $\mathrm{Fe}, \mathrm{Cu}, \mathrm{Mn}$, and $\mathrm{Zn}$ were within the typical background levels found in most non-polluted agricultural soils (Adriano, 2001; Kabata-Pendias, 2010). No one soil was consistently higher in all the elements measured and there was no consistent trend in the concentration of the elements with depth in each soil series.
The initial background levels of available nutrients are shown in Table 3. Means of the DTPA-extractable Fe, Mn, $\mathrm{Cu}$, and $\mathrm{Zn}$ are $5.30,5.01,0.81$, and $0.38 \mathrm{mg} \mathrm{kg}^{-1}$, respectively. These concentrations indicate an insufficient level of these nutrients and are typical of most semiarid soils (Havlin et al., 2013). Soil test $\mathrm{P}$ varied more widely, ranging from 8.93 to $123 \mathrm{mg} \mathrm{kg}^{-1}$, and was generally higher in the top soil, suggesting a possible $\mathrm{P}$ input to some of these soils through fertilization.

\subsection{Copper fixation pattern (short- and long-term examination)}

Percent estimates of fixed $\mathrm{Cu}$ determined after the first 14 days (designated as the short term), and 90 days (the long term) are presented in Table 4. The result is presented as the averages for all soils within each depth examined because the examination of individual soils showed no justifiable difference or pattern among the soils that is worth discussing. Comparison was made between the chelated and non-chelated micronutrient treatments. Average values from the three soil series examined revealed that within the nonchelated system, approximately 32 and $39 \%$ of the added $\mathrm{Cu}$ was fixed in the 0-15 and $15-30 \mathrm{~cm}$ depths, respectively, after the first 14 days. When compared to the chelated system, approximately 13.7 and $14.1 \%$ of the added $\mathrm{Cu}$ were fixed in the $0-15$ and $15-30 \mathrm{~cm}$ depths, respectively. The averages for both depths after the first 14 days were 35.5 and $13.9 \%$ for non-chelated and chelated systems, respectively. These numbers strongly suggest that chelating with EDTA reduced the fixation of $\mathrm{Cu}$ by soil constituents (Chiu et al., 2005), rendering $\mathrm{Cu}$ more available in these semiarid alkaline soils.

Copper fixation after 90 days (long-term fixation) was also examined. Approximately 48 and $56 \%$ of available $\mathrm{Cu}$ was fixed after 90 days in the non-chelated system within the 015 and $15-30 \mathrm{~cm}$ depths, respectively. These numbers compared to the chelated system were 43.2 and $47.2 \%$ for the 0-15 and 15-30 cm depths, respectively. Average fixations for both depths (all soils) after 90 days were $52.1 \%$ for the non-chelated system and $45.2 \%$ for the chelated system. The 
Table 3. Selected plant-available nutrients (in $\mathrm{m} \mathrm{kg}^{-1}$ ) in the studied semiarid alkaline soils of the Southern High Plains, USA.

\begin{tabular}{llccccc}
\hline Series & Sample ID & $\mathrm{Fe}_{\text {DTPA }}$ & $\mathrm{Mn}_{\text {DTPA }}$ & $\mathrm{Cu}_{\text {DTPA }}$ & $\mathrm{Zn}_{\text {DTPA }}$ & $\mathrm{P}_{\mathrm{M} 3}$ \\
\hline \multirow{2}{*}{ Amarillo } & $\mathrm{A} 2_{\mathrm{a}}$ & 9.73 & 4.53 & 0.97 & 0.96 & 123 \\
& $\mathrm{~A} 2 \mathrm{~b}$ & 3.32 & 3.25 & 0.54 & 0.20 & 58.7 \\
\multirow{3}{*}{ Mansker } & $\mathrm{M}_{\mathrm{a}}$ & 6.83 & 5.92 & 0.99 & 0.20 & 33.4 \\
& $\mathrm{M}_{\mathrm{b}}$ & 3.14 & 7.09 & 0.89 & 0.19 & 8.93 \\
Pullman & $\mathrm{P}_{\mathrm{a}}$ & 3.79 & 4.97 & 0.59 & 0.56 & 28.1 \\
& $\mathrm{P}_{\mathrm{b}}$ & 4.97 & 4.29 & 0.85 & 0.17 & 11.6 \\
\hline \multirow{2}{*}{ Mean } & & 5.30 & 5.01 & 0.81 & 0.38 & 44.0 \\
Standard deviation & 2.57 & 1.34 & 0.19 & 0.32 & 42.7 \\
\hline
\end{tabular}

Abbreviations: DTPA: diethylene triamine pentaacetic acid; M3: Mehlich 3.

Table 4. Average percentage (with standard deviation) of plantavailable copper fixed after 14 and 90 days in the non-chelated and chelated systems of the semiarid alkaline soils of the Southern High Plains, USA.

\begin{tabular}{lllr|r}
\hline & & & \multicolumn{2}{c}{ Percentage fixed after } \\
\cline { 3 - 5 } Cu system & \multicolumn{2}{l}{ Depth $(\mathrm{cm})$} & 14 days & 90 days \\
\hline \multirow{2}{*}{ Non-chelated } & $0-15$ & $(n=3)$ & $32.0(6.0) \mathrm{a}$ & $48.4(12.1) \mathrm{a}$ \\
& $15-30$ & $(n=3)$ & $39.1(9.8) \mathrm{a}$ & $55.9(2.7) \mathrm{a}$ \\
\cline { 2 - 5 } & All & $(n=6)$ & $35.5(2.2) \mathrm{A}$ & $52.1(7.3) \mathrm{A}$ \\
\hline Chelated & $0-15$ & $(n=3)$ & $13.7(9.2) \mathrm{a}$ & $43.2(0.4) \mathrm{a}$ \\
& $15-30$ & $(n=3)$ & $14.1(11.9) \mathrm{a}$ & $47.2(7.4) \mathrm{a}$ \\
\cline { 2 - 5 } & All & $(n=6)$ & $13.9(10.4) \mathrm{B}$ & $45.2(3.5) \mathrm{A}$ \\
\hline
\end{tabular}

Mean values within a column in a given $\mathrm{Cu}$ system with the same lowercase letter and mean values within a column for the $\mathrm{Cu}$ systems with the same upper case letter are not statistically different (Fisher's LSD $\alpha=0.05$ ).

findings indicated a narrower difference of approximately $7 \%$ between the non-chelated and chelated systems in the long term (90 days) compared to the $22 \%$ observed in the short term (14 days). This could possibly be attributed to the fact that the strength of the chelate decreases with time; thus, more $\mathrm{Cu}$ is fixed by other soil constituents over time. The findings here are partly supported by the study of Meers et al. (2005), who estimated a half life of 39 to 59 days for EDTA in doses of 0.8 to $1.6 \mathrm{mmol}$ experimented in a heavy metal phytoextraction study, suggesting that the effectiveness of EDTA on micronutrient mobilization in soil systems will decrease over time. The slightly higher fixation of $\mathrm{Cu}$ in the subsurface soil could be partly attributed to its higher clay content. Strong soil-clay-heavy-metal interactions have previously been documented in soils of this region (Udeigwe et al., 2015) and such interactions could reduce the amount of plant-extractable $\mathrm{Cu}$.

\subsection{Changes in available $\mathrm{Cu}$ with respect to other micronutrients}

The changes in the concentration of available $\mathrm{Cu}$ over the experimental period of 90 days were compared to those of other micronutrients in the mixture. Relationships within individual soils were examined, but this did not show findings worth focusing the discussion on; thus the findings summarized are averages for the soils at each depth and for both depths combined (Table 5). Regression analyses were used to evaluate the strengths of the relationships and to further examine the gradient of the change between $\mathrm{Cu}$ and each of the other micronutrient elements. In each depth, the amount of available $\mathrm{Cu}$ positively and significantly changes with each of the other micronutrients, although to varying degrees.

Overall, the strengths of the relationships were higher in the non-chelated systems $\left(R^{2}: 0.68-0.94\right)$ compared to the chelated $\left(R^{2}: 0.42-0.81\right)$. For each of the relationships examined, the slope was generally higher in the non-chelated systems, suggesting that more $\mathrm{Cu}$ will be fixed for each unit of the other micronutrients fixed in the non-chelated system. The findings indicate that in each depth, the change in available $\mathrm{Cu}$ with respect to change in $\mathrm{Zn}(\mathrm{Cu}-\mathrm{Zn})$ was higher than those of $\mathrm{Cu}-\mathrm{Fe}$, and $\mathrm{Cu}-\mathrm{Mn}$ in both the non-chelated and chelated systems, as evidenced from the slope of the equations. When both depths were combined for each element, within the non-chelated system, the slopes were 0.40 $(\mathrm{Cu}-\mathrm{Fe}), 0.31(\mathrm{Cu}-\mathrm{Mn})$, and $1.04(\mathrm{Cu}-\mathrm{Zn})$, and $0.26(\mathrm{Cu}-$ $\mathrm{Fe}), 0.22(\mathrm{Cu}-\mathrm{Mn})$, and $0.90(\mathrm{Cu}-\mathrm{Zn})$ for the chelated system. Within the non-chelated system, the findings suggest that a $1 \mathrm{mg} \mathrm{kg}^{-1}$ change in the concentration of available Fe, $\mathrm{Mn}$, and $\mathrm{Zn}$, is associated with a $0.40,0.31$, and $1.04 \mathrm{mg} \mathrm{kg}^{-1}$ change in available $\mathrm{Cu}$, respectively, in these semiarid alkaline soils of the SHP. The information obtained here has not previously been reported for these soils and provides a good approximation of how $\mathrm{Cu}$ changes in respect to other micronutrients in both chelated and non-chelated systems in these semiarid alkaline soils. 
Table 5. Changes in available copper with respect to other micronutrient elements ( $\mathrm{Fe}, \mathrm{Mn}$, and $\mathrm{Zn})$ in the non-chelated and chelated systems of the studied semiarid alkaline soils of the Southern High Plains, USA $(n=9)$.

\begin{tabular}{lll|ll|ll}
\hline & \multicolumn{2}{c}{ Fe } & Mn & Zn \\
\hline \multicolumn{7}{c}{ Non-chelated } \\
\hline $0-15$ & $y=0.35 x-0.17$ & $0.91^{\mathrm{b}}$ & $y=0.25 x+1.95$ & $0.77^{\mathrm{b}}$ & $y=0.92 x+0.80$ & $0.92^{\mathrm{b}}$ \\
$15-30$ & $y=0.45 x-0.04$ & $0.84^{\mathrm{c}}$ & $y=0.38 x+1.20$ & $0.68^{\mathrm{b}}$ & $y=1.14 x+0.95$ & $0.94^{\mathrm{c}}$ \\
All & $y=0.40 x-0.13$ & $0.90^{\mathrm{c}}$ & $y=0.31 x+1.59$ & $0.77^{\mathrm{b}}$ & $y=1.04 x+0.83$ & $0.93^{\mathrm{c}}$ \\
\hline \multicolumn{7}{c}{ Chelated } \\
\hline $0-15$ & $y=0.24 x+1.41$ & $0.74^{\mathrm{b}}$ & $y=0.17 x+3.29$ & $0.52^{\mathrm{a}}$ & $y=0.86 x+0.87$ & $0.78^{\mathrm{b}}$ \\
15-30 & $y=0.27 x+2.45$ & $0.78^{\mathrm{b}}$ & $y=0.30 x+2.76$ & $0.59^{\mathrm{a}}$ & $y=0.64 x+2.43$ & $0.42^{\mathrm{a}}$ \\
All & $y=0.26 x+1.89$ & $0.81^{\mathrm{c}}$ & $y=0.22 x+3.14$ & $0.56^{\mathrm{a}}$ & $y=0.90 x+1.05$ & $0.65^{\mathrm{b}}$ \\
\hline
\end{tabular}

${ }^{\mathrm{a}}$ significant at $\alpha=0.05 ;{ }^{\mathrm{b}}$ significant at $\alpha=0.01 ;{ }^{\mathrm{c}}$ significant at $\alpha=0.001$.

Table 6. Kinetic models used for the study of copper fixation in selected semiarid alkaline soils of the Southern High Plains, USA.

\begin{tabular}{lll}
\hline Kinetic model & Equation & Parameter \\
\hline Zero-order & $q_{t}=q_{0}-k_{0} t$ & $k_{0}$, zero-order rate constant $\left(\mathrm{mg} \mathrm{kg}^{-1} \mathrm{~d}^{-1}\right)$ \\
First-order & $\ln q_{t}=\ln q_{0}-k_{1} t$ & $k_{1}$, first-order rate constant $\left(\mathrm{d}^{-1}\right)$ \\
Second-order & $1 / q_{t}=1 / q_{0}-k_{2} t$ & $k_{2}$, second-order rate constant $\left(\mathrm{mg} \mathrm{kg}^{-1}\right)^{-1}$ \\
Power function & $q_{t}=a_{t}^{b}$ & $a$, initial reaction magnitude constant $\left(\mathrm{mg} \mathrm{kg}^{-1}\left(\mathrm{~h}^{-1}\right)^{b}\right)$ \\
& & and $b$, reaction rate constant $\left(\mathrm{mg} \mathrm{kg}^{-1}\right)^{-1}$ \\
\hline
\end{tabular}

$q_{0}$ and $q_{t}$ are the amount of micronutrients at time zero and $t$, respectively.

(a)

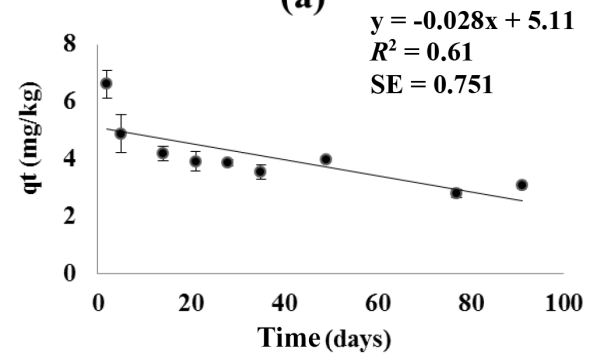

(c)

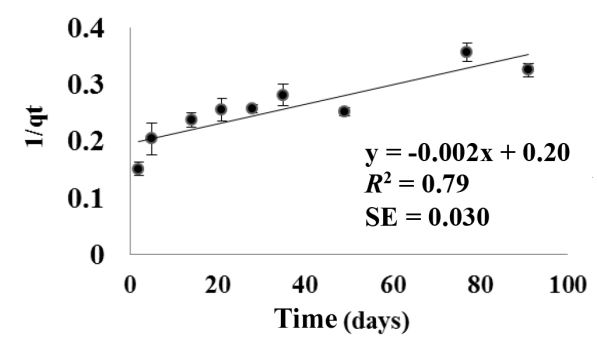

(b)

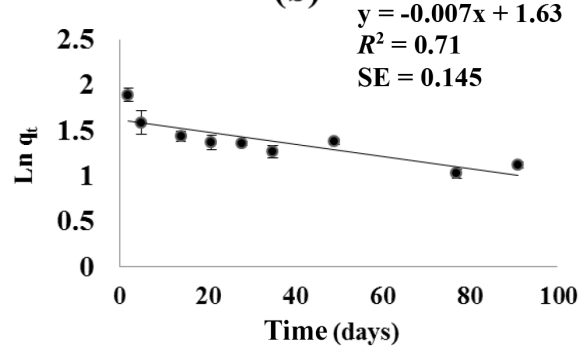

(d)

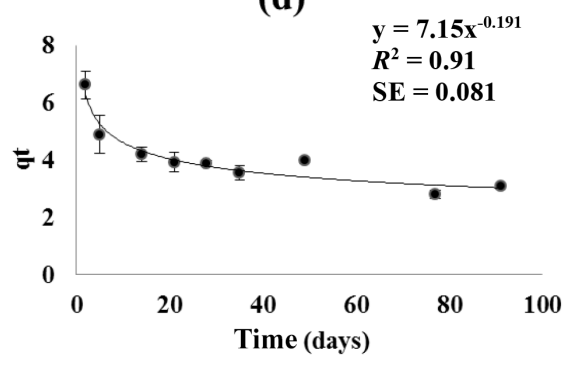

Figure 1. Amount of diethylene triamine pentaacetic acid (DTPA)-extractable copper over the long term (90 days) in the non-chelated system fitted to (a) zero-order, (b) first-order, (c) second-order, and (d) power function models $\left(q_{t}\right.$ denotes the amount remaining at time $t\left(\mathrm{mg} \mathrm{kg}^{-1}\right)$; error bars are for standard errors computed from six data points). 
(a)

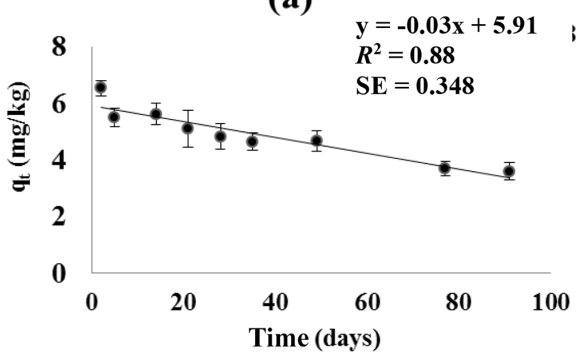

(c)

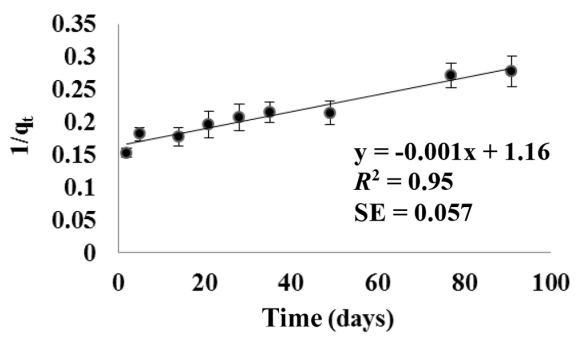

(b)

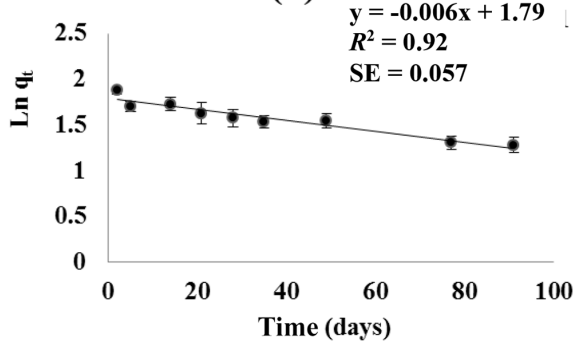

(d)

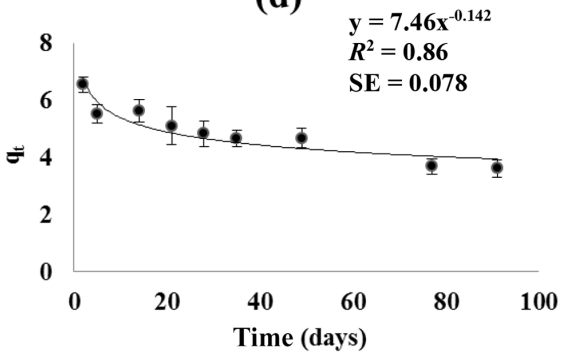

Figure 2. Amount of diethylene triamine pentaacetic acid (DTPA)-extractable copper over the long term (90 days) in the chelated system fitted to (a) zero-order, (b) first-order, (c) second-order, and (d) power function models $\left(q_{t}\right.$ denotes the amount remaining at time $t\left(\mathrm{mg} \mathrm{kg}^{-1}\right)$; error bars are for standard errors computed from six data points).

Table 7. Experimental data from copper kinetic studies fitted to zero-, first-, and second-order models, and power function models.

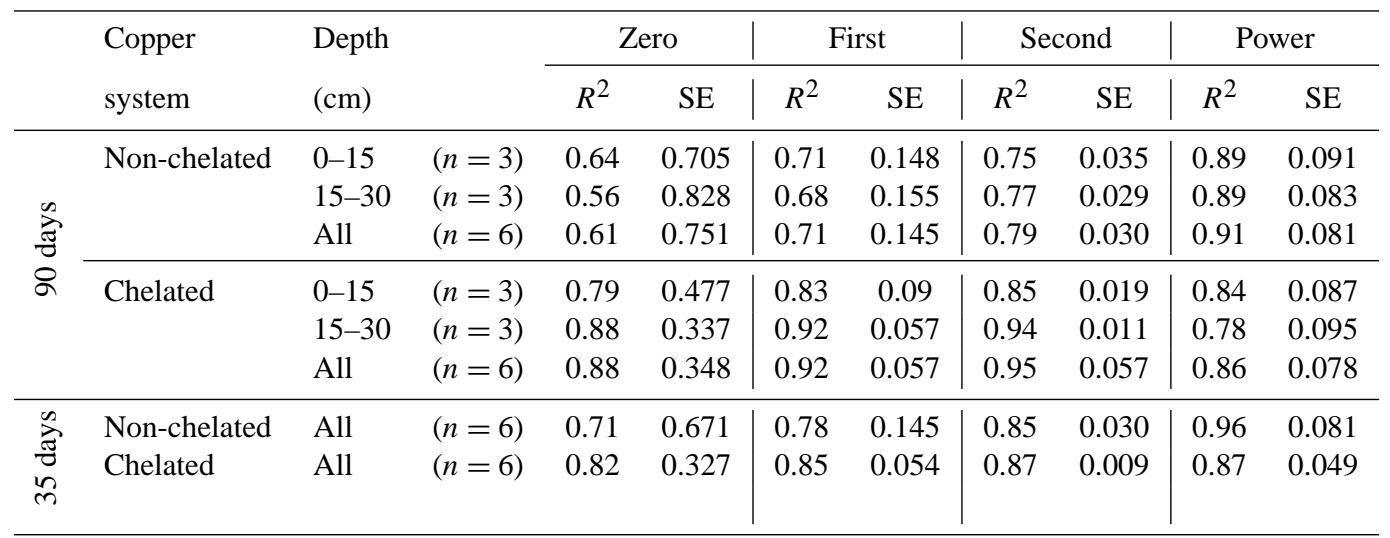

SE: standard error of regression line.

\subsection{Kinetics of copper fixation}

Copper fixation in the chelated and non-chelated systems were further examined by fitting the data obtained from kinetic experiments to various kinetic models. A number of kinetic models (Table 6) were examined based on the experimental conditions of this study and evidence gathered from previous studies (Dang et al., 1994; Reyhanitabar and Gilkes, 2010; Rajashekhar Rao, 2015). Coefficient of determination $\left(R^{2}\right)$ and standard error (SE) were employed as criteria for evaluating the best fit among the models examined (Dang et al., 1994; Reyharitabar and Gilkes, 2010). Fixation kinetics were studied within soils and depths. However, the individual examination of soils did not show justifiable reasons to focus the discussion on the comparison among them as earlier intended. Thus, for further examination, average data points for all three soils were used, an approach that also enhanced the statistical evaluations.

Experimental data from kinetic studies were fitted to zero-, first-, and second-order models, as well as to power function models, and findings are summarized in Table 7. In all the models, $q_{t}$ represents the amount of DTPA-extractable (plant-available) $\mathrm{Cu}$ remaining at time $t$, in days. Close examination reveals a comparable trend between the depths of $0-15$ and $15-30 \mathrm{~cm}$ and hence there were no findings among 
(a)

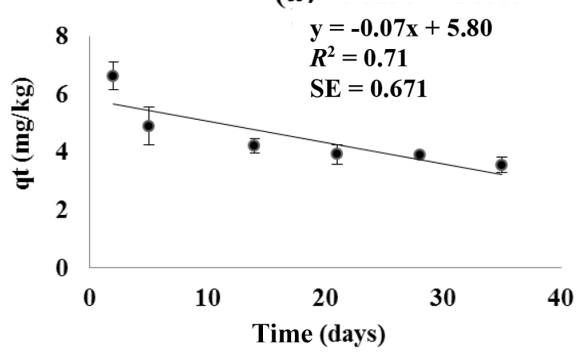

(c)

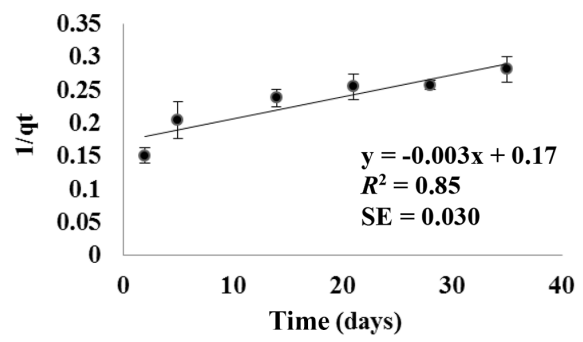

(b)

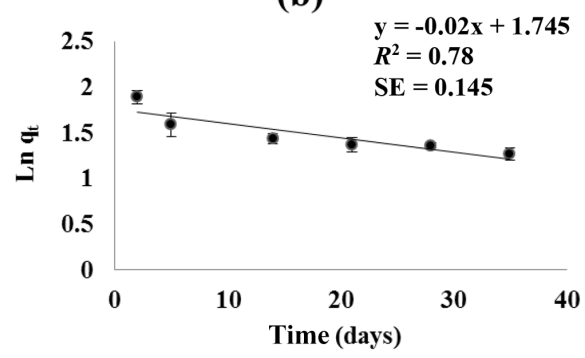

(d)

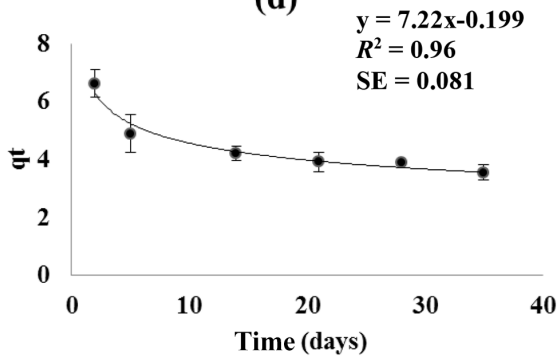

Figure 3. Amount of diethylene triamine pentaacetic acid (DTPA)-extractable copper over the short term (35 days) in the non-chelated system fitted to (a) zero-order, (b) first-order, (c) second-order, and (d) power function models $\left(q_{t}\right.$ denotes the amount remaining at time $t$ $\left(\mathrm{mg} \mathrm{kg}^{-1}\right)$; error bars are for standard errors computed from six data points).

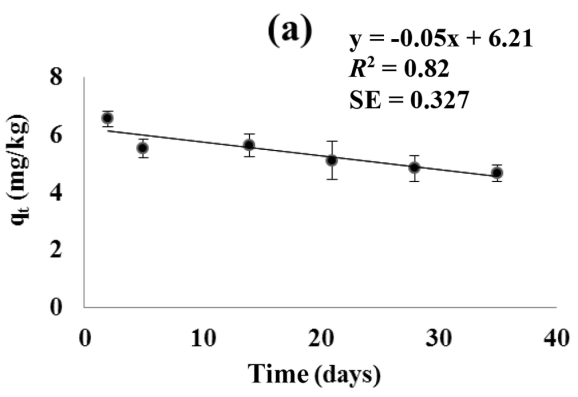

(c)

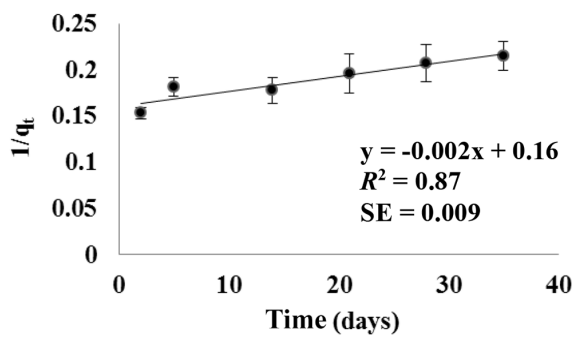

(b) $y=-0.009 x+1.83$ $R^{2}=0.85$ $\mathrm{SE}=\mathbf{0 . 0 5 4}$

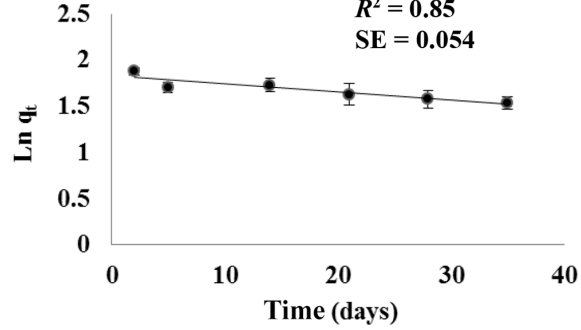

(d)

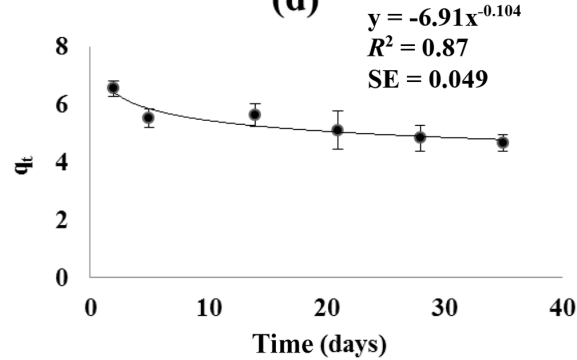

Figure 4. Amount of diethylene triamine pentaacetic acid (DTPA)-extractable copper over the short term (35 days) in the chelated system fitted to (a) zero-order, (b) first-order, (c) second-order, and (d) power function models $\left(q_{t}\right.$ denotes the amount remaining at time $t\left(\mathrm{mg} \mathrm{kg}^{-1}\right)$; error bars are for standard errors computed from six data points).

depths worth discussing. As a result, discussions will be concentrated on models derived using the average values of all soils and depths. It was evident that fixation of available $\mathrm{Cu}$ was poorly described by the zero-, first-, and second-order models $\left(R^{2}: 0.61-0.79\right.$, SE: $\left.0.030-0.751\right)$ but slightly better by the power function model $\left(R^{2}=0.91, \mathrm{SE}=0.081\right)$. A better fit to the power function model suggests that the fixation of plant-available $\mathrm{Cu}$ in this mixed system of non-chelated micronutrients is somewhat nonlinear over the 90 days' experimental period (Fig. 1), an indication of a more com- 
plex reaction type. This finding was similar to that obtained when $\mathrm{Cu}$ was examined in a single system (data not shown). Within the chelated system, the finding was somewhat different (Fig. 2) as $\mathrm{Cu}$ fixation was better described by the secondorder model $\left(R^{2}=0.95, \mathrm{SE}=0.010\right)$ compared to the other models $\left(R^{2}: 0.86-0.92\right)$. This better fit to the second-order model could imply that the reaction rate depends on the concentration of two reactants (Evangelou, 1998; Sparks, 2003), i.e., $\mathrm{Cu}$ and another soil constituents, for e.g., other micronutrients such as $\mathrm{Fe}, \mathrm{Mn}$, or $\mathrm{Zn}$. In retrospect, a better fit to the zero-order model implies that the rate of reaction does not depend on the concentration of the reactant $(\mathrm{Cu})$, while a better fit to the first-order model will imply that the rate of reaction is dependent on the concentration of only one reactant (e.g., Cu) (Evangelou, 1998; Sparks, 2003).

Further examination of the data points suggests a possible discontinuity in the slope or pattern of the data distribution before and after day 35 , suggesting a likely difference in the mechanisms of $\mathrm{Cu}$ fixation before and after the first 35 days. These sets of data points were further separated and examined (Fig. 3 and Table 7). Within the non-chelated system, $\mathrm{Cu}$ fixation in the first 35 days was better described by the power function model $\left(R^{2}=0.96, \mathrm{SE}=0.081\right)$ (Fig. 3). When compared to the chelated system, $\mathrm{Cu}$ fixation followed the second-order and power function models more closely at about the same degree $\left(R^{2}=0.87\right)$ (Fig. 4). The findings revealed that the reduction in the amount of available $\mathrm{Cu}$ occurred at a slower pace in the chelated system compared to the non-chelated system as evidenced from the reaction rate constants of 0.104 and $0.192 \mathrm{mg} \mathrm{kg}^{-1}$ day $^{-1}$, respectively.

\subsection{Significance of findings to copper management}

The adherence of the fixation of non-chelated $\mathrm{Cu}$ in the examined semiarid soils to the power function model is an indication of a more complex reaction type when compared to the chelated $\mathrm{Cu}$ which followed the second-order model. Findings substantiate the need to apply $\mathrm{Cu}$ micronutrient in the chelated form on these semiarid soils as significantly less chelated $\mathrm{Cu}$ was fixed, particularly within the first 14 days. Findings further suggest the significance of timing, given that about $68 \%$ of the total $\mathrm{Cu}$ fixed was in the first 14 days and that the effectiveness of the chelated compound tended to decrease over time, leading to a narrower difference between chelated and non-chelated compounds. The relationships developed from the examination of the change in available $\mathrm{Cu}$ with respect to other micronutrients could be used as predictive tools. The reaction rate constants obtained from this study could be used to approximate how much of added $\mathrm{Cu}$ micronutrient will be available at a specific point in time in both chelated and non-chelated systems in these semiarid soils. A very important application of the findings from this study will be for the comparison of the fixation pattern of $\mathrm{Cu}$ to those of other micronutrients within these semiarid soils. Reaction rate constants could be compared to those ob- tained for $\mathrm{Cu}$ in other soils. The applications developed from this study provide a basis for a more mechanistic approach to evaluating the effectiveness of commercial micronutrient products and comparisons among products by examining their fixation patterns and kinetic parameters. A database of the reaction rate constants derived for different chelated and non-chelated $\mathrm{Cu}$ compounds can be compared among themselves and used as a tool for making a more informed decision on $\mathrm{Cu}$ management on these semiarid soils.

\section{Conclusions}

Kinetic models could be used to further our understanding and examine $\mathrm{Cu}$ fixation in soils of the semiarid to arid climates. The reduction of plant-available $\mathrm{Cu}$ more closely followed the power function and second-order models in the non-chelated and chelated systems, respectively. The findings substantiate the need for the use of chelated compounds and the importance of timing in $\mathrm{Cu}$ management in these semiarid soils. Reaction rate constants obtained from this study could be used for the comparison of the fixation pattern of $\mathrm{Cu}$ to those of other micronutrients within these semiarid soils, and for comparisons among soils, and also provide a more mechanistic basis for evaluating the effectiveness of different $\mathrm{Cu}$ compounds. Results from this study have much practical significance.

Acknowledgements. The authors acknowledge the College of Agricultural Sciences and Natural Resources, Texas Tech University, for providing the research enhancement funds that partly supported this study.

Edited by: A. Jordán

\section{References}

Abbas, M. H. and Salem, H. M.: Kinetics of iron retention by typic torriorthent and typic haplocalcid soils supplied with some micronutrients, Ann. Agric. Sci. Moshtohor, 49, 301-311, 2011.

Adriano, D. C.: Trace Elements in Terrestrial Environments: Biogeochemistry, Bioavailability, and Risks of Metals, Springer Science and Business Media, New York, USA, 2001.

Allen, V. G., Brown, C. P., Kellison, R., Segarra, E., Wheeler, T., Dotray, P. A., Conkwright, J. C., Green, C. J., and AcostaMartinez, V.: Integrating cotton and beef production to reduce water withdrawal from the Ogallala Aquifer in the Southern High Plains, Agron. J., 97, 556-567, 2005.

Alloway, B. J. (Ed.): Micronutrient Deficiencies in Global Crop Production, Springer Science and Business Media, Berlin, Germany, 2008.

Amuti, T. and Luo, G.: Analysis of land cover change and its driving forces in a desert oasis landscape of Xinjiang, northwest China, Solid Earth, 5, 1071-1085, doi:10.5194/se-5-1071-2014, 2014. 
Barbero-Sierra, C., Marques, M. J., Ruiz-Pérez, M., Escadafal, R., and Exbrayat, W.: How is desertification research addressed in Spain? Land versus soil approaches, Land Degrad. Develop., 26, 423-432, 2015.

Bindraban, P. S., Dimkpa, C., Nagarajan, L., Roy, A., and Rabbinge, R.: Revisiting fertilisers and fertilization strategies for improved nutrient uptake by plants, Biol. Fertil. Soils, 51, 1-15, doi:10.1007/s00374-015-1039-7, 2015.

Chesworth, W. (Ed.): Encyclopedia of Soil Science, Springer Science and Business Media, Berlin, Germnay, 2008.

Chiu, K. K., Ye, Z. H., and Wong, M. H.: Enhanced uptake of As, $\mathrm{Zn}$, and $\mathrm{Cu}$ by Vetiveria zizanioides and Zea mays using chelating agents, Chemosphere, 60, 1365-1375, 2005.

Dang, Y. P., Dalal, R. C., Edwards, D. G., and Tiller, K. G.: Kinetics of zinc desorption from vertisols, Soil Sci. Soc. of Am. J., 58, 1392-1399, 1994.

De Schamphelaere, K. A., Vasconcelos, F. M., Tack, F. M., Allen, H. E., and Janssen, C. R.: Effect of dissolved organic matter source on acute copper toxicity to Daphnia magna, Environ. Toxicol. Chem., 23, 1248-1255, 2004.

Dimkpa, C. O., Latta, D. E., McLean, J. E., Britt, D. W., Boyanov, M. I., and Anderson, A. J.: Fate of $\mathrm{CuO}$ and $\mathrm{ZnO}$ nano and micro particles in the plant environment, Environ Sci. Technol., 47, 4734-4742, 2013.

Evangelou, V. P.: Environmental Soil and Water Chemistry: Principles and Applications, Wiley, New York, USA, 1998.

Fernández-Calviño, D., Garrido-Rodríguez, B., López-Periago, J. E., Paradelo, M., and Arias-Estévez, M.: Spatial distribution of copper fractions in a vineyard soil, Land Degrad. Dev., 24, 556563, 2013.

Gee, G. W. and Bauder. J. W.,: Particle-size analysis, in: Methods of Soil Analysis, Part 1 - Pyhiscal and Mineralogical Methods, edited by: Klute, A., Soil Sci. Soc. of Am., Madison, WI, USA, 383-411, 1986.

Havlin, J. L. T., Nelson, S. L., and Beaton, J. D.: Soil fertility and fertilizers: an introduction to nutrient management, 8th edn., Pearson, Upper Saddle River, New Jersey, USA, 2013.

Kabata-Pendias, A.: Trace Elements in Soils and Plants, 3rd edn., Google eBook, CRC Press, Boca Raton, Florida, USA, 2000.

Kayser, A., Wenger, K., Keller, A., Attinger, W., Felix, H. R., Gupta, S. K., and Schulin, R.: Enhancement of phytoextraction of $\mathrm{Zn}, \mathrm{Cd}$, and $\mathrm{Cu}$ from calcareous soil: the use of NTA and sulfur amendments, Environ. Sci. Technol., 34, 1778-1783, 2000.

Liang, J. and Karamanos, R. E.: DTPA-extractable Fe, Mn, Cu and $\mathrm{Zn}$, in: Soil Sampling and Methods of Analysis, edited by: Carter, M. R., CRC Press, Boca Raton, Florida, USA, 1993.

Lindsay, W. and Norvell, W. A.: Development of a DTPA soil test for zinc, iron, manganese, and copper, Soil Sci. Soc. of Am. J., 42, 421-428, 1978.

Luo, C., Shen, Z., and Li, X.: Enhanced phytoextraction of $\mathrm{Cu}$, $\mathrm{Pb}, \mathrm{Zn}$ and $\mathrm{Cd}$ with EDTA and EDDS, Chemosphere, 59, 1-11, 2005.

Manouchehri, N., Besancon, S., and Bermond, A.: Major and trace metal extraction from soil by EDTA: equilibrium and kinetic studies, Anal. Chim. Acta, 559, 105-112, 2006.

Meers, E., Ruttens, A., Hopgood, M. J., Samson, D., and Tack, F. M. G.: Comparison of EDTA and EDDS as potential soil amendments for enhanced phytoextraction of heavy metals, Chemosphere, 58, 1011-1022, 2005.
Mehlich, A.: Mehlich 3 soil test extractant: a modification of Mehlich 2 extractant, Commun. Soil Sci. Plant Anal., 15, 14091416, 1984.

Mehta, S., Fryar, A. E., and Banner, J. L.: Controls on the regionalscale salinization of the Ogallala aquifer, Southern High Plains, Texas, USA. Appl. Geochm., 15, 849-864, 2000.

Mureithi, S. M., Verdoodt, A., Njoka, J. T., Gachene, C. K. K., and Van Ranst, E.: Benefits derived from rehabilitating a degraded semi-arid rangeland in communal enclosures, Kenya, Land Degrad. Develop., doi:10.1002/ldr.2341, 2015.

Nelson, D. W. and Sommers, L. E.: Total carbon, organic carbon, and organic matter, Methods of soil analysis - Part 2, Chemical and microbiological properties, (methodsofsoilan2), 539579, 1982.

Pinto, A. P., Mota, A. M., De Varennes, A., and Pinto, F. C.: Influence of organic matter on the uptake of cadmium, zinc, copper and iron by sorghum plants, Sci. Total Environ., 326, 239-247, 2004.

Rajashekhar Rao, B. K.: Kinetics of potassium release in sweet potato cropped soils: a case study in the highlands of Papua New Guinea, Solid Earth, 6, 217-225, doi:10.5194/se-6-2172015, 2015.

Rashid, A. and Ryan, J.: Micronutrient constraints to crop production in soils with Mediterranean-type characteristics: a review, J. Plant Nutr., 27, 959-975, 2004.

Reyhanitabar, A. and Gilkes, R. J.: Kinetics of DTPA extraction of zinc from calcareous soils, Geoderma, 154, 289-293, 2010.

Sarah, P. and Zonana, M.: Livestock redistribute runoff and sediments in semi-arid rangeland areas, Solid Earth, 6, 433-443, doi:10.5194/se-6-433-2015, 2015.

Sekhon, B. S.: Chelates for micronutrient nutrition among crops, Resonance, 8, 46-53, 2003.

Soil Survey Staff: Kellogg Soil Survey Laboratory Methods Manual. Soil Survey Investigations Report No. 42, Version 5.0., edited by: Burt, R. and Soil Survey Staff, US Department of Agriculture, Natural Resources Conservation Service, Lincoln, NE, USA, 2014.

Sparks, D. L.: Environmental Soil Chemistry, 2nd edn., Academic Press, California, USA, 2003.

Sparks, D. L., Page, A. L., Helmke, P. A., Loeppert, R. H., Soltanpour, P. N., Tabatabai, M. A., and Sumner, M. E.: Methods of soil analysis, Part 3-Chemical methods, Soil Sc. Soc. of Am. Inc., Madison, WI, USA, 1996.

Stout, J. E.: Dust and environment in the southern high plains of North America, J. Arid Environ., 47, 425-441, 2001.

Torres, L., Abraham, E. M., Rubio, C., Barbero-Sierra, C., and Ruiz-Pérez, M.: Desertification research in Argentina, Land Degrad. Develop., 26, 433-440, 2015.

Udeigwe, T. K., Wang, J. J., and Zhang, H.: Effectiveness of bauxite residues in immobilizing contaminants in manure-amended soils, Soil Sci., 174, 676-686, 2009.

Udeigwe, T. K., Young, J., Kandakji, T., Weindorf, D. C., Mahmoud, M. A., and Stietiya, M. H.: Elemental quantification, chemistry, and source apportionment in golf course facilities in a semi-arid urban landscape using a portable X-ray fluorescence spectrometer, Solid Earth, 6, 415-424, doi:10.5194/se-6415-2015, 2015.

United States Environmental Protection Agency-Inductively Coupled Plasma (USEPA-ICP) Users Group: Method 200.7, 
available at: http://www.nmenv.state.nm.us/gwb/documents/ DairyRegs/NOIAttachment9-Exhibits/3224Exhibits/3224-1. pdf (last access: 3 September 2015), 1982.

World Health Organization (WHO): Guidelines on food fortification with micronutrients, available at: http://whqlibdoc.who.int/ publications/2006/9241594012_eng.pdf?ua=1\&ua=1 (last access: 3 September 2015), 2000.
Young, J., Udeigwe, T. K., Weindorf, D. C., Kandakji, T., Gautam, P., and Mahmoud, M. A.: Evaluating management-induced soil salinization in golf courses in semi-arid landscapes, Solid Earth, 6, 393-402, doi:10.5194/se-6-393-2015, 2015. 